\title{
Parallel regional convergence in Poland before and after EU accession
}

\begin{abstract}
The purpose of the study is to analyze the dynamics of regional disparities on NUTS 2 level in Poland for the period 1990-2017 within the framework of sigma convergence. We focus in particular on comparing the patterns of regional convergence before and after EU accession, introducing the methodology of parallel sigma convergence. The results show that the Mazowieckie voivodeship grew much above the average in both the preand post-accession periods, while eastern regions lagged behind. EU accession did not have a significant impact on the pattern of internal sigma convergence in Poland. Disparities between regions were increasing at the same pace before and after 2004, despite significant resources having been allocated to cohesion-focused undertakings after EU accession, especially in lagging eastern regions.
\end{abstract}

Keywords

Regional convergence $\bullet$ EU accession $\bullet$ parallel convergence $\bullet$ sigma $\bullet$ Poland

(c) University of Warsaw - Faculty of Geography and Regional Studies

\author{
Piotr Wójcik @e \\ Faculty of Economic Sciences, \\ University of Warsaw, Poland \\ e-mail: pwojcik@wne.uw.edu.pl \\ Received: 10 March 2020 \\ Accepted: 4 January 2021
}

Introduction

One of the topics on economic growth most frequently raised in the economic literature in the last 30 years has been the question of real economic convergence between countries and regions (Barro \& Sala-i-Martin 2004). The European Union aims at reducing regional disparities. Regions with relative per capita GDP below $75 \%$ of the EU average receive support from Structural Funds and the Cohesion Fund. At the time of Poland's accession to the European Union, all Polish regions had incomes below this threshold and received financial support. The five poorest Polish regions of Eastern Poland received greater per capita support than other regions (see Table 2). One might expect this to have increased territorial cohesion among Polish regions after EU accession.

The purpose of this study is to analyze the dynamics of regional disparities in Poland for the period 1990-2017 within the framework of sigma convergence. We focus in particular on comparing the patterns of regional convergence before and after 2004. The research hypothesis is that joining the EU did not significantly change the patterns of regional convergence in Poland. The innovation of the study presented in this article consists in analyzing the longest period ever considered in regional convergence studies for Poland (28 years) and the two equally long sub-periods before and after EU accession (14 years each). In addition, we use a novel methodology of parallel sigma convergence, which is useful for evaluation and statistical comparison of patterns of convergence.

The remaining part of the article is structured in the following way: first we review the main concepts of convergence, and parallel convergence is introduced. Then, based on the literature review, research gaps are identified. This is followed by a description of the data and empirical analysis, and then a summary with conclusions.
Real economic convergence and the concept of parallel convergence

Real economic convergence means faster growth of poorer regions (or countries) relative to richer ones. It results in disparities between regions being reduced. The opposite phenomenon is called divergence. There are two main concepts of real convergence in the economic literature - sigma and beta (Barro \& Sala-i-Martin 1992). Beta convergence focuses on the relationship between the average growth rate and initial level of income. It occurs if per capita income grows more quickly for initially poorer regions. Beta convergence is verified through regression analysis where the dependent variable is the annual growth rate and the only independent variable is initial GDP per capita if analyzing absolute convergence (all regions converging to a common steady state), or additional independent variables are included if analyzing conditional convergence (to individual steady states). Estimation can be performed on crosssectional data or panel data. However, a negative relationship between growth rate and initial level of income does not imply a decrease in the dispersion measure. Moreover, such a negative relationship may occur even in the case of divergence. Therefore, beta convergence is not very informative if one is interested in changes in the distribution of income. Analysis of sigma convergence consists in analyzing the trend in a selected measure of income dispersion in successive periods. Sigma convergence occurs when the dispersion of income per capita between regions, usually measured by standard deviation or coefficient of variation, decreases over time. Its major advantage is the ease of interpretation of the result and the possibility of clear graphic presentation (see, for example, Figure 4 later in the text). Hence, in this paper we focus on sigma convergence, as it allows it to be determined whether regional inequalities 


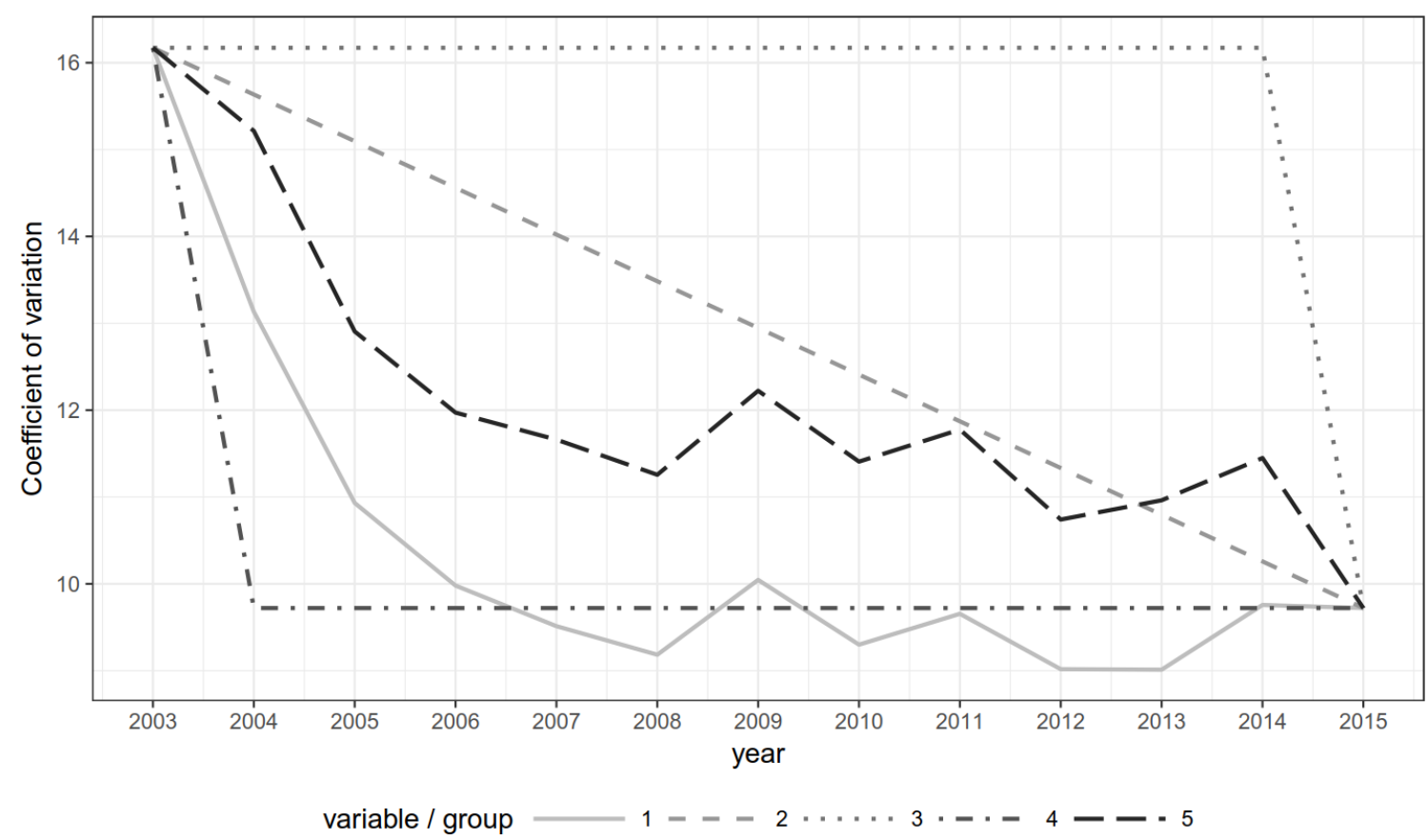

Figure 1. Sample plot of coefficients of variation for five artificial measurements with an identical mean slope Source: own elaboration

change over time. Parallel convergence is a concept introduced by Wójcik (2018) and describes the case in which two compared measurements portray identical (statistically indistinguishable) dynamics of economic convergence processes. It can be used to analyze similarities in convergence patterns in different contexts: two different phenomena, two different groups of regions or regional levels, or two different periods. ${ }^{1}$ The existence of parallel sigma convergence is verified by plotting the evolution of dispersion measures for two compared samples on a single graph and testing whether the two plot lines are parallel. In the simplest case it means checking whether the lines for the two measurements have the same average slope. A more restrictive variant requires that the lines (all their segments) are parallel in each subperiod. To compare the slopes (trends), a standard t-test for the equality of means in paired samples can be used, or the non-parametric Wilcoxon signed rank test. For the more restrictive variant, Wójcik (2018) introduces an indicator called the mean absolute difference in slopes (MADiS) and suggests testing whether it is equal to zero. For each period, one compares two sigma convergence lines and, if dispersion of both measurements changes in the same way, the slopes of lines are deemed to be equal. The difference is slopes can be either positive or negative. To avoid positive and negative differences from different periods cancelling each other out, one takes into account the absolute (signless) value of the difference. Therefore, if data points are regularly spaced in time, the value of MADiS is calculated as:

MADiS $=\frac{1}{T-1} \sum_{t=2}^{T}\left|\left(s_{1, t}-s_{1, t-1}\right)-\left(s_{2, t}-s_{2, t-1}\right)\right|$

where $T$ is the number of periods, $s_{1, t}$ and $s_{2, t}$ are the values of a dispersion measure for the 1st and 2nd measurements,

${ }^{1}$ See Wójcik (2018) for a detailed explanation and sample applications respectively, and $s_{i t}-s_{i t-1}$ is the slope for measurement $i$ ( $i=$ $1,2)$ in period $t$. Because the number of periods is usually relatively small, and MADiS does not have any known theoretical distribution, bootstrapped confidence intervals are used. ${ }^{2}$ The assumption that lines representing measures of dispersion are exactly parallel in all periods (MADiS $=0$ ) is very strong. It can be weakened, alternatively assuming that parallel convergence occurs when inequalities for both measurements change in the same direction year by year - whenever dispersion of one phenomenon increases, the same happens for the other. This means that in all periods the sign of the slopes of the lines is the same or that the mean absolute difference in the slopes' signs (MADiSS) is equal to zero. The value of MADiSS can be calculated from the formula:

MADiSS $=\frac{1}{T-1} \sum_{t=2}^{T}\left|\operatorname{sign}\left(s_{1, t}-s_{1, t-1}\right)-\operatorname{sign}\left(s_{2, t}-s_{2, t-1}\right)\right|$

Here too, the bias corrected confidence intervals of Efron (1987) are used.

To illustrate the advantage of MADiS and MADiSS over taking into account only the average slope of the dispersion lines, we present coefficients of variation for five artificial measurements with an identical mean slope over some sample period (Figure 1). The average slope will be exactly equal in a situation when the measure of variability in the entire period decreases or increases by the same value, but changes occur in completely different sub-periods or their dynamics is different.

The values of MADiS and MADiSS for each pair of five artificial measurements together with their $95 \%$ bootstrapped confidence intervals are presented in Table 1.

${ }^{2}$ We use the bias corrected confidence intervals suggested by Efron (1987) 
Table 1. Values of MADiS and MADiSS together with 95\% bootstrapped confidence intervals for five artificial measurements with an identical mean slope

\begin{tabular}{|c|c|c|c|c|c|c|c|c|}
\hline statistic & \multicolumn{5}{|c|}{ MADiS } & \multicolumn{4}{c|}{ MADiSS } \\
\hline group & $\mathbf{2}$ & $\mathbf{3}$ & $\mathbf{4}$ & $\mathbf{5}$ & $\mathbf{2}$ & $\mathbf{3}$ & $\mathbf{4}$ & $\mathbf{5}$ \\
\hline \multirow{2}{*}{1} & 0.82 & 1.40 & 0.90 & 0.43 & 0.50 & 0.92 & 0.92 & 0.17 \\
& $(0.50,1.35)$ & $(0.70,2.89)$ & $(0.51,1,66)$ & $(0.13,0,96)$ & $(0.05,1.08)$ & $(0.58,1.00)$ & $(0.56,1.00)$ & $(0.00,0.81)$ \\
\hline \multirow{2}{*}{2} & & 0.99 & 0.99 & 0.76 & & 0.92 & 0.92 & 0.67 \\
& & $(0.54,2.69)$ & $(0.54,2.60)$ & $(0.50,1,09)$ & & $(0.54,1.00)$ & $(0.45,1.00)$ & $(0.15,1.23)$ \\
\hline \multirow{2}{*}{3} & & & 1.07 & 1.13 & & & 0.17 & 0.92 \\
& & & $(0.00,3.03)$ & $(0.67,2.19)$ & & & $(0.00,0.45)$ & $(0.54,1.00)$ \\
\hline \multirow{2}{*}{4} & & & & 1.26 & & & & 0.92 \\
& & & & $(0.72,2.81)$ & & & & $(0.50,1.00)$ \\
\hline
\end{tabular}

Source: own elaboration

The parallelism of lines representing the dynamics of variation in individual variants will be confirmed if the confidence interval spans zero (i.e. ranges from a negative to a positive value) - then the value of the statistic is not significantly different from zero. The values of MADIS and MADISS are presented together with their confidence intervals in Table 1. The parallelism of the coefficient of variation lines was found only for the pair in which the slopes for most periods are equal to zero (group 3 and group 4 ), although the MADiS value for this pair is quite high (1.07). The lowest value of MADiS (in line with intuition) was noted for groups 1 and 5 , which have a similar pattern of variation. However, in the case of restrictive comparison of slopes in individual periods, the mean absolute difference in slopes turns out to be significantly different from zero in this case. Similarly for MADiSS, the equality of the slopes of the coefficient of variation was confirmed for group 3 and group 4 . The value of MADiSS for this pair is the lowest (also as expected). This time, however, the same result (no significant differences in the signs of the slope of the variation line) was obtained for the pair of groups 1 and 5 , which have a very similar pattern of variation.

\section{Literature review}

In 2004, all Polish NUTS2 regions had incomes below $75 \%$ of the EU average and received financial support. The five poorest Polish regions - all in Eastern Poland (Lubelskie, Podkarpackie, Podlaskie, Świętokrzyskie and Warmińsko-Mazurskie) - received greater support than other regions in terms of cumulative value of EU funds disbursed per capita and in relation to their regional GDP (see Table 1). EU funds are assumed to contribute to strengthening economic growth by increasing innovation and global competitiveness of lagging regions. However, evaluation studies show that mainly the development of infrastructure is financed, which contributes to raising the standard of living of the inhabitants (Wojtowicz 2020). All voivodeships decreased their distance in terms of GDP per capita relative to the EU28 average, but the gap closed most slowly in the eastern regions. Their relative income per capita increased by $9.7-12.9$ p.p. with the mean of 20.9 p.p. for all regions. However, the Cohesion Policy seems to have been successful in the eastern regions as a large share of their catching-up process is a result of having received EU funds (Table 2).

Apart from external convergence observed in all voivodeships, it is also interesting to analyze whether and how the disparities between regions changed over time. Piętak (2015) analyzed convergence patterns across Polish NUTS 2 regions between 2005 and 2011 and observed beta and sigma divergence of per capita GDP. Sigma divergence of Polish regions was found in many studies for different periods, e.g. 1995-2010 (Kusideł 2013), 2000-12 (Wędrowska \& Wojciechowska 2015). Wałęga (2014) claims that in 2005-09 there was an increase in the distance between regions as compared to $2000-04$, but does not test that statistically. Czudec \& Kata (2016) claim that there has been significant progress in reducing development gaps between the regions of Eastern and Western Poland thanks to the allocation of significant resources from the Structural Funds after EU accession. However, the analysis takes into account only the period 2004-14, without comparing convergence patterns prior to EU accession. Wójcik (2017) shows that in the first ten years after 2004 neither beta nor sigma convergence was observed at the regional level in Poland. The post-EU-accession period has seen accelerated divergence processes in Poland. The differences in rate of development between the initially richest regions and the poorest increased even further after EU accession. Churski and Perdał (2016) identify $22 \%$ of counties (LAU 1 - former NUTS 4 ) as nodes of development. In the period $2004-10$ these regions received $45 \%$ of the total allocation of EU funds (119\% of the national per capita average). In contrast, $26 \%$ of counties classified as development peripheries acquired only $20 \%$ of the total allocation of EU funds ( $85 \%$ of the national per capita average). The greatest funding was received by the areas with the highest initial development usually large cities - rather than the lagging regions. They were better prepared to take part in competitive procedures of applying for EU funds. Development peripheries faced important barriers in accessing EU funds, including their lower competitive advantage in fund-requesting procedures due to lower investment efficiency indicators, excessive own financial contribution and inadequate human resources of local administration.

On the other hand, Horridge and Rokicki (2018) show that the poorest Polish regions gained most from the 2004 accession. They apply regional dynamic computable general equilibrium (CGE) models to simulate the growth of regional per capita income for the Visegrad countries in the period 2000-13 at the NUTS 2 level. The authors conclude that all regions would have grown at a slower pace without EU membership and that the EU structural policies played a key role here. According to those authors, with no EU accession, or with accession but without Cohesion Policy, regional disparities in Poland would have increased even faster, especially after 2008 .

Based on the previous studies we identify two important research gaps. First, although convergence is a long-term 
MISCELLANEA GEOGRAPHICA - REGIONAL STUDIES ON DEVELOPMENT

Vol. $25 \cdot$ No. $2 \cdot 2021 \cdot$ pp. 83-92 •ISSN: 2084-6118 • DOI: 10.2478/mgrsd-2020-0050

Table 2. The impact on EU funds on external convergence of Polish regions to EU28 average in the period 2004-2018

\begin{tabular}{|c|c|c|c|c|c|}
\hline \multirow{2}{*}{ voivodeship } & \multicolumn{3}{|c|}{ Cumulative value of EU funds disbursed } & \multicolumn{2}{|c|}{ convergence to EU28 average GDP } \\
\hline & mIn PLN & per capita (PLN) & share of GDP & total in p.p. & share resulting from Cohesion Policy \\
\hline Dolnośląskie & 33085,0 & 11404 & $1,6 \%$ & 26,0 & $12,3 \%$ \\
\hline Kujawsko-pomorskie & 18391,0 & 8852 & $1,7 \%$ & 12,2 & $22,0 \%$ \\
\hline Lubelskie & 23889,2 & 11286 & $2,5 \%$ & 12,4 & $25,0 \%$ \\
\hline Lubuskie & 11253,0 & 11092 & $2,1 \%$ & 13,0 & $24,0 \%$ \\
\hline Łódzkie & 28974,5 & 11748 & $2,0 \%$ & 18,9 & $17,0 \%$ \\
\hline Małopolskie & 30494,3 & 8967 & $1,6 \%$ & 19,0 & $14,0 \%$ \\
\hline Mazowieckie & 68836,7 & 12739 & $1,3 \%$ & 35,6 & $10,0 \%$ \\
\hline Opolskie & 9579,7 & 9711 & $1,8 \%$ & 12,5 & $20,0 \%$ \\
\hline Podkarpackie & 28306,3 & 13295 & $2,9 \%$ & 12,0 & $31,0 \%$ \\
\hline Podlaskie & 14025,7 & 11871 & $2,5 \%$ & 12,9 & $27,0 \%$ \\
\hline Pomorskie & 27822,7 & 11923 & $2,0 \%$ & 17,9 & $18,0 \%$ \\
\hline Śląskie & 40477,4 & 8928 & $1,3 \%$ & 16,0 & $14,0 \%$ \\
\hline Świętokrzyskie & 13614,9 & 10966 & $2,3 \%$ & 9,7 & $29,0 \%$ \\
\hline Warmińsko-mazurskie & 22942,2 & 16055 & $3,4 \%$ & 11,0 & $45,0 \%$ \\
\hline Wielkopolskie & 29823,8 & 8536 & $1,3 \%$ & 22,2 & $11,5 \%$ \\
\hline Zachodniopomorskie & 19697,5 & 11580 & $2,1 \%$ & 12,7 & $25,0 \%$ \\
\hline Poland & 421213,9 & 10966 & $1,7 \%$ & 20,9 & $15,0 \%$ \\
\hline
\end{tabular}

Source: Ministry of Development Funds and Regional Policy (2019)

phenomenon, research for Poland at a regional level usually covers short periods. This is due to the lack of sufficiently long time series available, which results from numerous changes in territorial units (especially NUTS3) and the lack of official backward estimates. Therefore, in this article, we analyze the longest period for which statistical data or reliable estimates are available - 1990-2017 for NUTS2 regions. Importantly, it covers an equally long period before and after Poland's accession to the EU. Second, comparison of convergence patterns for different periods is done only with explanatory statistics - no tests are used to verify the statistical significance of differences. In this article the methodology of parallel sigma convergence will be applied to test the main research hypothesis that Poland's accession to the European Union had no significant impact on the dynamics of regional convergence processes.

\section{Data sources}

Two alternative datasets are used - the Local Data Bank of the Polish Central Statistical Office (CSO, a.k.a. Statistics Poland) and Cambridge Econometrics European Regional Database (ERD) - see ERD (2017). ERD provides a complete and consistent historical time series of data. GDP per capita (in purchasing power standard) for Polish NUTS 2 regions is available for 1990 to 2015 and has previously been used in convergence studies (Herz \& Vogel 2013). Data for 2016 and 2017 was added from the CSO dataset. The second source of data on GDP per capita for Polish NUTS 2 regions is CSO. Current CSO data for the period 2000-17 include all ex-post corrections, which may not yet be included in the ERD. Data for 1995-99 are a retrospective estimate made by Zienkowski (2000). Estimates for the years 199094 are based on a World Bank report prepared by Czyżewski (1998). Data were converted into the new administrative system introduced in Poland in 2000 proportionally to the population size, assuming that the level of GDP per capita was the same in all municipalities of the "old" region. ${ }^{3}$

\section{Empirical results}

For both sources, GDP per capita for each region was transformed into a relative value (divided by the appropriate country average), which allows for easy comparability of the data over time. There are important differences in the data for initial years of analysis (1990-94) between ERD and CSO. For example, GDP per capita in 1990 seems to be much more evenly distributed among regions in ERD with an important exception for Świętokrzyskie, which reaches only $56 \%$ of the national average in ERD while it ranges to $81 \%$ in CSO - see Figures $2 \mathrm{a}$ and $2 \mathrm{~b}$.

For the years 1995-99 differences between datasets are much smaller, and after 2000 are negligible - see Figures 2c-2f for comparison of relative GDP per capita in 2003 and 2017. Mazowieckie is the richest region at the beginning, and during the study period grows the fastest and further increases its advantage over all other regions. Five regions of Eastern Poland (Świętokrzyskie, Podkarpackie, Lubelskie, Podlaskie and

${ }^{3}$ The estimates of GDP for 1990-1994 should be treated with some caution, especially as they have been additionally converted into a new administrative system. 
a) 1990 (CSO)

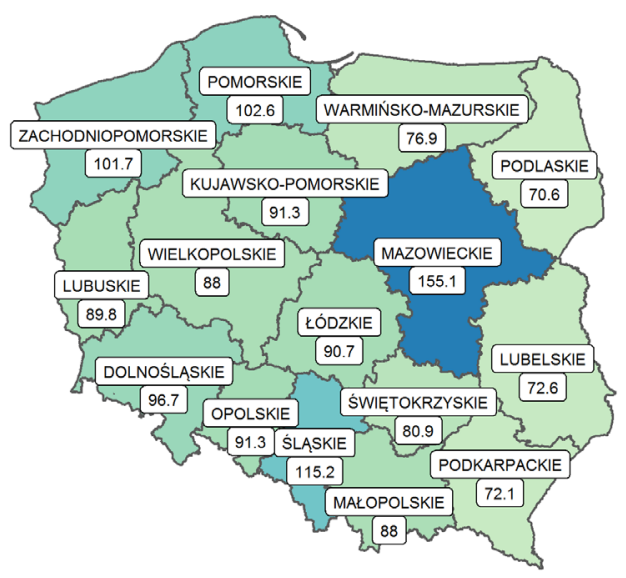

c) 2003 (CSO)

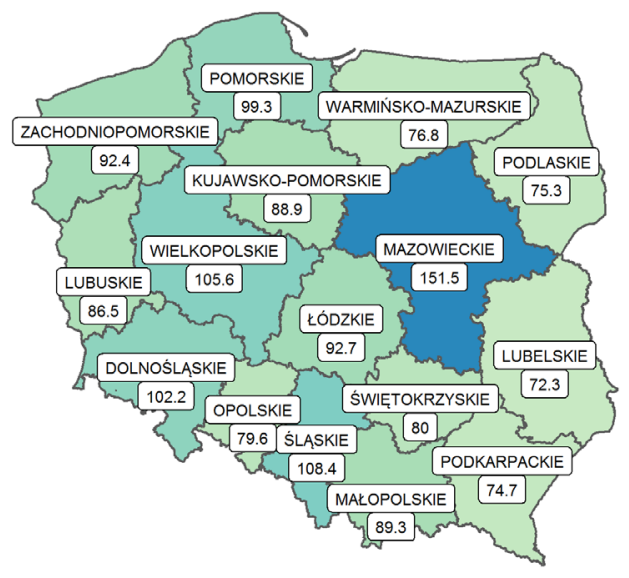

e) 2017 (CSO)

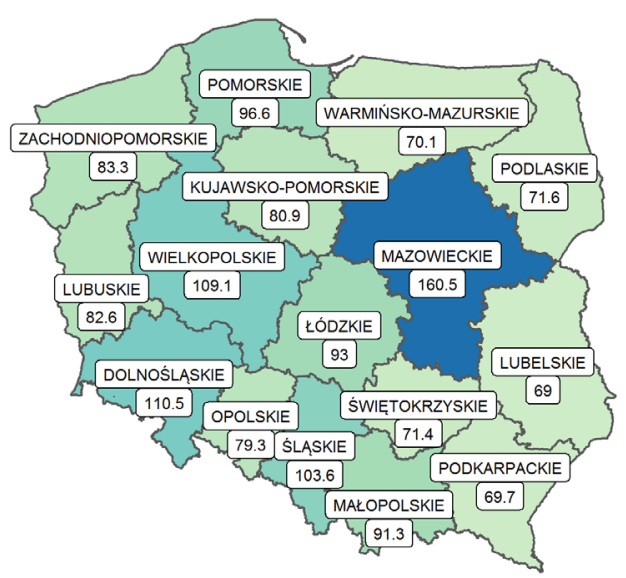

b) 1990 (ERD)

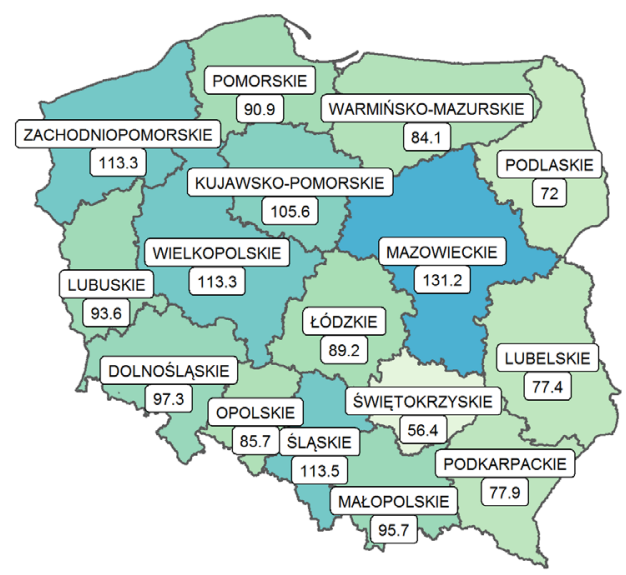

d) 2003 (ERD)

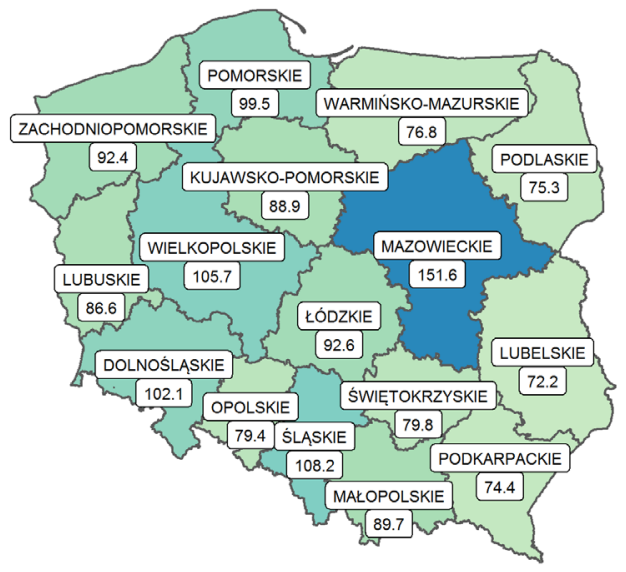

f) 2017 (ERD)

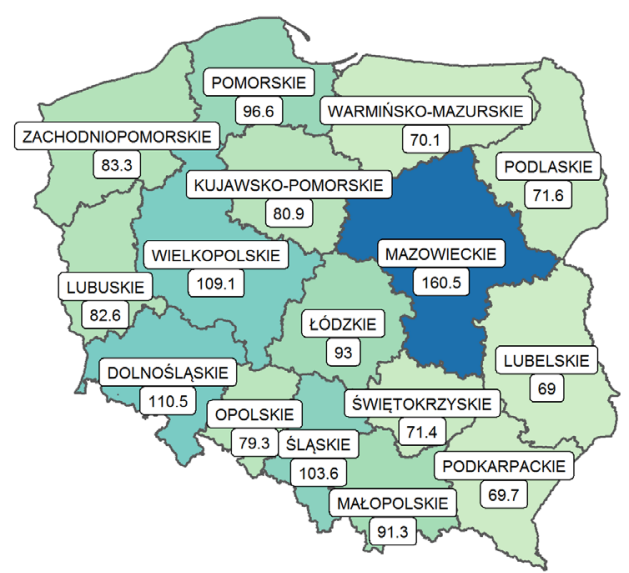

$\begin{array}{lllllllllllll}50 & 60 & 70 & 80 & 90 & 100 & 110 & 120 & 130 & 140 & 150 & 160 & 170\end{array}$

Figure 2. Maps of relative GDP per capita in 1990, 2003 and 2017

Source: own calculations based on data from CSO and ERD 
MISCELLANEA GEOGRAPHICA - REGIONAL STUDIES ON DEVELOPMENT

Vol. 25 • No. 2 - 2021 • pp. 83-92 • ISSN: 2084-6118 • DOI: 10.2478/mgrsd-2020-0050

Table 3. Relative GDP per capita of Polish NUTS 2 regions in 1990-2017

\begin{tabular}{|c|c|c|c|c|c|c|c|c|c|c|}
\hline region & 1990 & 1993 & 1996 & 1999 & 2003 & 2006 & 2009 & 2012 & 2015 & 2017 \\
\hline Dolnośląskie & 97,3 & 98,9 & 100,3 & 102,4 & 102,1 & 107,4 & 109,2 & 113,6 & 111,6 & 110,5 \\
\hline Kujawsko-Pomorskie & 105,6 & 100,5 & 94,9 & 90,8 & 88,9 & 86,6 & 83,9 & 81,2 & 81,5 & 80,9 \\
\hline Lubelskie & 77,4 & 75,6 & 73,4 & 71,6 & 72,2 & 69,0 & 69,0 & 69,9 & 68,3 & 69,0 \\
\hline Lubuskie & 93,6 & 92,8 & 91,2 & 92,0 & 86,6 & 90,0 & 85,6 & 83,0 & 83,5 & 82,6 \\
\hline Łódzkie & 89,2 & 90,2 & 91,0 & 89,8 & 92,6 & 92,1 & 91,6 & 92,4 & 92,7 & 93,0 \\
\hline Małopolskie & 95,7 & 93,0 & 90,5 & 89,8 & 89,7 & 90,2 & 88,9 & 88,5 & 90,3 & 91,3 \\
\hline Mazowieckie & 131,2 & 137,9 & 144,4 & 147,8 & 151,6 & 154,7 & 155,7 & 158,6 & 158,5 & 160,5 \\
\hline Opolskie & 85,7 & 85,3 & 84,8 & 85,6 & 79,4 & 81,6 & 82,2 & 83,3 & 83,4 & 79,3 \\
\hline Podkarpackie & 77,9 & 76,0 & 73,9 & 73,3 & 74,5 & 71,5 & 70,7 & 70,5 & 71,3 & 69,7 \\
\hline Podlaskie & 72,1 & 72,4 & 72,2 & 73,2 & 75,3 & 72,7 & 73,6 & 72,4 & 71,9 & 71,6 \\
\hline Pomorskie & 90,9 & 93,4 & 95,6 & 99,4 & 99,5 & 98,9 & 98,6 & 98,0 & 96,2 & 96,6 \\
\hline Śląskie & 113,5 & 111,5 & 111,5 & 108,9 & 108,2 & 106,0 & 106,2 & 105,8 & 103,9 & 103,6 \\
\hline Świętokrzyskie & 56,4 & 63,2 & 69,6 & 76,3 & 79,8 & 77,9 & 79,1 & 74,6 & 72,3 & 71,4 \\
\hline Warmińsko-Mazurskie & 84,1 & 83,7 & 82,6 & 79,9 & 76,8 & 74,7 & 73,7 & 71,9 & 71,3 & 70,1 \\
\hline Wielkopolskie & 113,3 & 110,0 & 106,8 & 106,1 & 105,7 & 106,6 & 107,9 & 105,4 & 108,3 & 109,1 \\
\hline Zachodniopomorskie & 113,3 & 108,6 & 103,5 & 99,8 & 92,4 & 90,1 & 87,5 & 84,1 & 85,2 & 83,3 \\
\hline
\end{tabular}

Source: own calculation based on ERD data

Warmińsko-Mazurskie) are the poorest at the beginning and the gap between them and the rest clearly increases over time. We consider data from ERD for the first few years of transformation to be more reliable than our own rough approximations. Table 3 shows relative GDP per capita for each NUTS2 region over the whole analyzed period 1990-2017.

We can clearly observe that Mazowieckie was always much richer than all other regions, and developed much faster than the other regions. There were two other successful regions that grew faster than the average: Dolnośląskie and Świętokrzyskie (or Wielkopolskie in CSO data). Half of the regions did not change their relative income much. The largest decreases in relative income were recorded in Zachodniopomorskie and KujawskoPomorskie, while slightly smaller decreases were found in Warmińsko-Mazurskie, Śląskie and Lubuskie. Figure 3 shows annual average change in relative GDP per capita in the whole period under study (1990-2017), before EU accession (19902003) and after Poland joined the EU (2004-17). The picture does not seem to differ much between the two subperiods Mazowieckie grows much above the average, while the eastern regions lag behind. The relative decline in per capita GDP in these regions is even steeper after 2004. This observation is confirmed by direct comparison of the convergence patterns in these two subperiods.

Figure 4 compares the values of coefficient of variation of relative GDP per capita in Polish regions in 1990-2017 calculated based on both datasets. The huge decrease in disparities between 1992 and 1996 observed in the CSO data is mainly the result of temporary decreases in estimated GDP for Mazowieckie and Śląskie and increases in Wielkopolskie, Łódzkie, Lubuskie and Podlaskie in the same period. ERD data for the same years are much smoother (see Figure 4), which results in more stable values of the dispersion measure. Irrespective of the dataset applied, we observe an increasing trend before and after EU accession (the latter period is indicated by the shaded background).

To directly compare the dispersion measures in successive years of the two periods we plotted Figure 5, which juxtaposes the superimposed plots for the 14-year period before EU accession and the same plots for the 14 years after accession. This allows easier analysis of similarities in general trends and year-by-year slopes between the two periods.

The scale of the bottom horizontal axis on the graphs refers to the 14-year period before EU accession (1990-2003) while the scale of the top horizontal axis refers to the 14-year period after EU accession (2004-17). Black lines show the dynamics of inequalities over the analyzed period (dashed lines for the first period and solid for the second). Gray lines (similarly dashed and solid) show the trend of sigma convergence in each period. One can observe that, irrespective of the dataset analyzed, regional inequalities are greater after joining the EU than before. In addition, in both periods inequalities clearly increase and the slopes of the trends seem to be comparable, especially for the CSO data. To formally verify whether the trends of convergence were identical before and after EU accession (i.e. parallel gray lines from Figure 5) we employ a parametric t-test for the equality of two means in paired samples, and a non-parametric Wilcoxon test for the equality of two distributions. To ensure the robustness of results we compare different numbers of years $(5,6, \ldots, 13)$ before and after EU accession. The results of the tests are presented in Table 4.

Irrespective of the test applied, dataset used or number of years compared, in each case, the null hypothesis - that the 
a) $1990-2017$ (CSO)

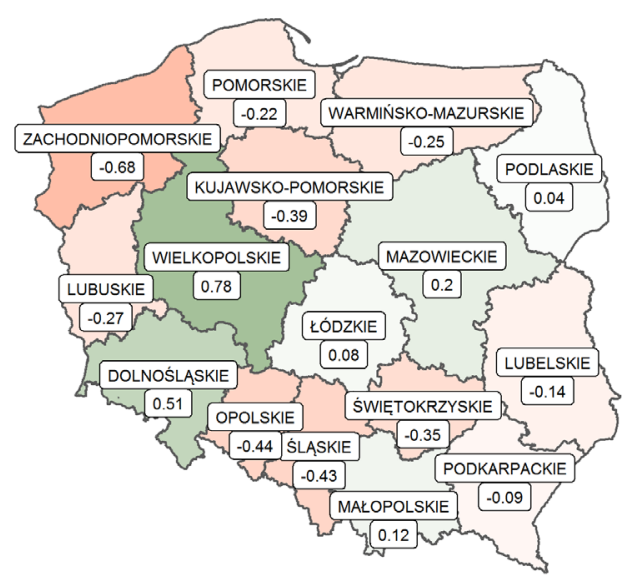

c) $1990-2003$ (CSO)

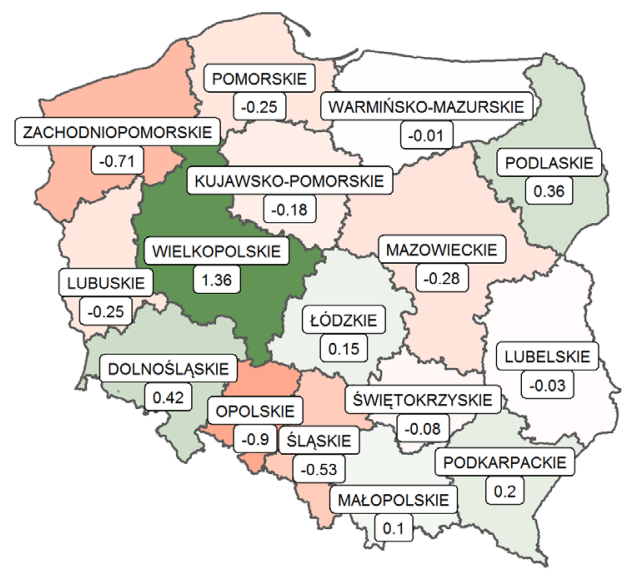

e) 2004-2017 (CSO)

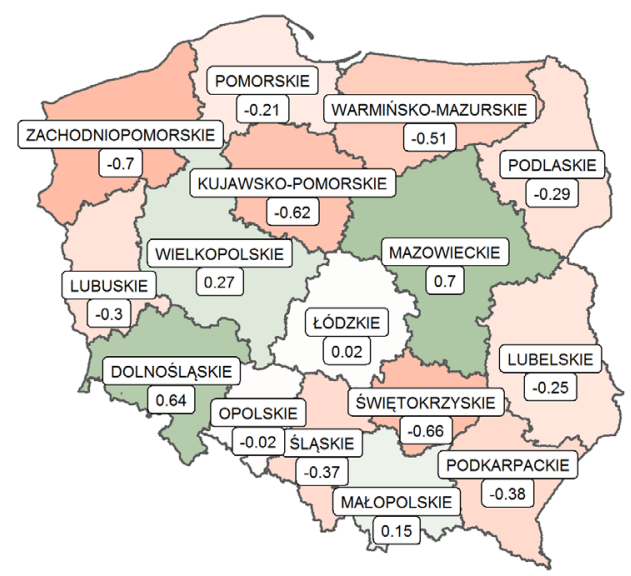

b) $1990-2017$ (ERD)

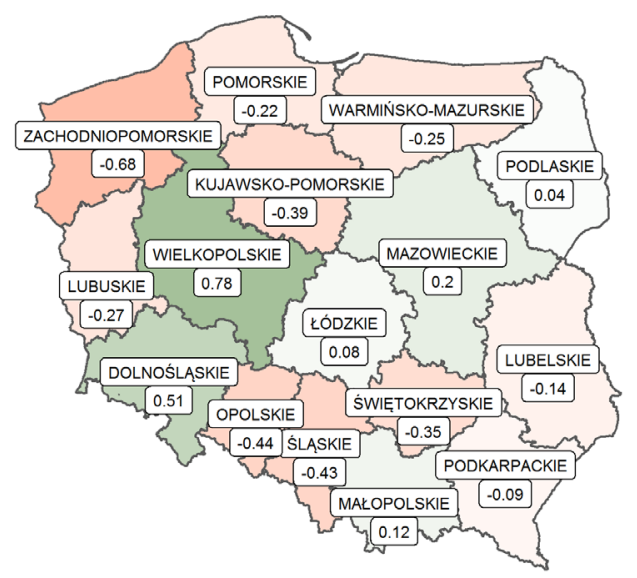

d) $1990-2003(E R D)$

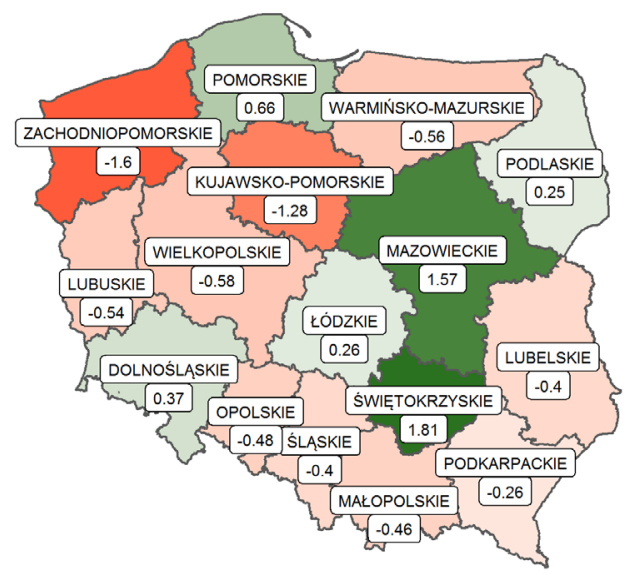

f) $2004-2017$ (ERD)

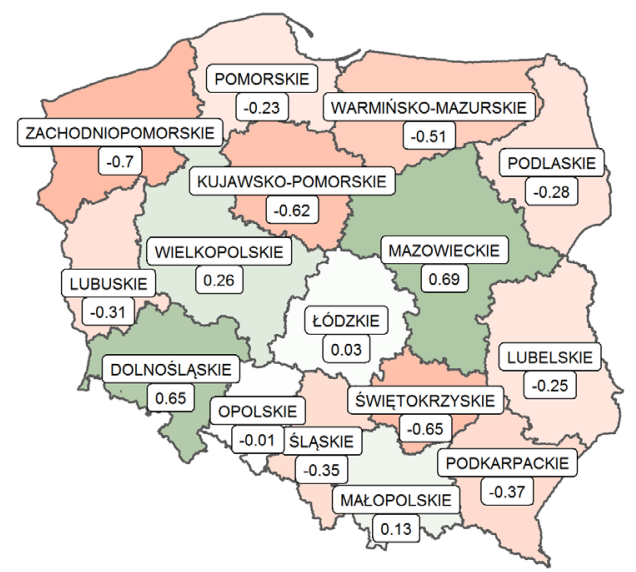

$\begin{array}{lllllllll}-2.0 & -1.5 & -1.0 & -0.5 & 0.0 & 0.5 & 1.0 & 1.5 & 2.0\end{array}$

Figure 3. Average annual change in relative GDP per capita in 1990-2017, 1990-2003 and 2004-17 Source: own calculations based on data from CSO and ERD 


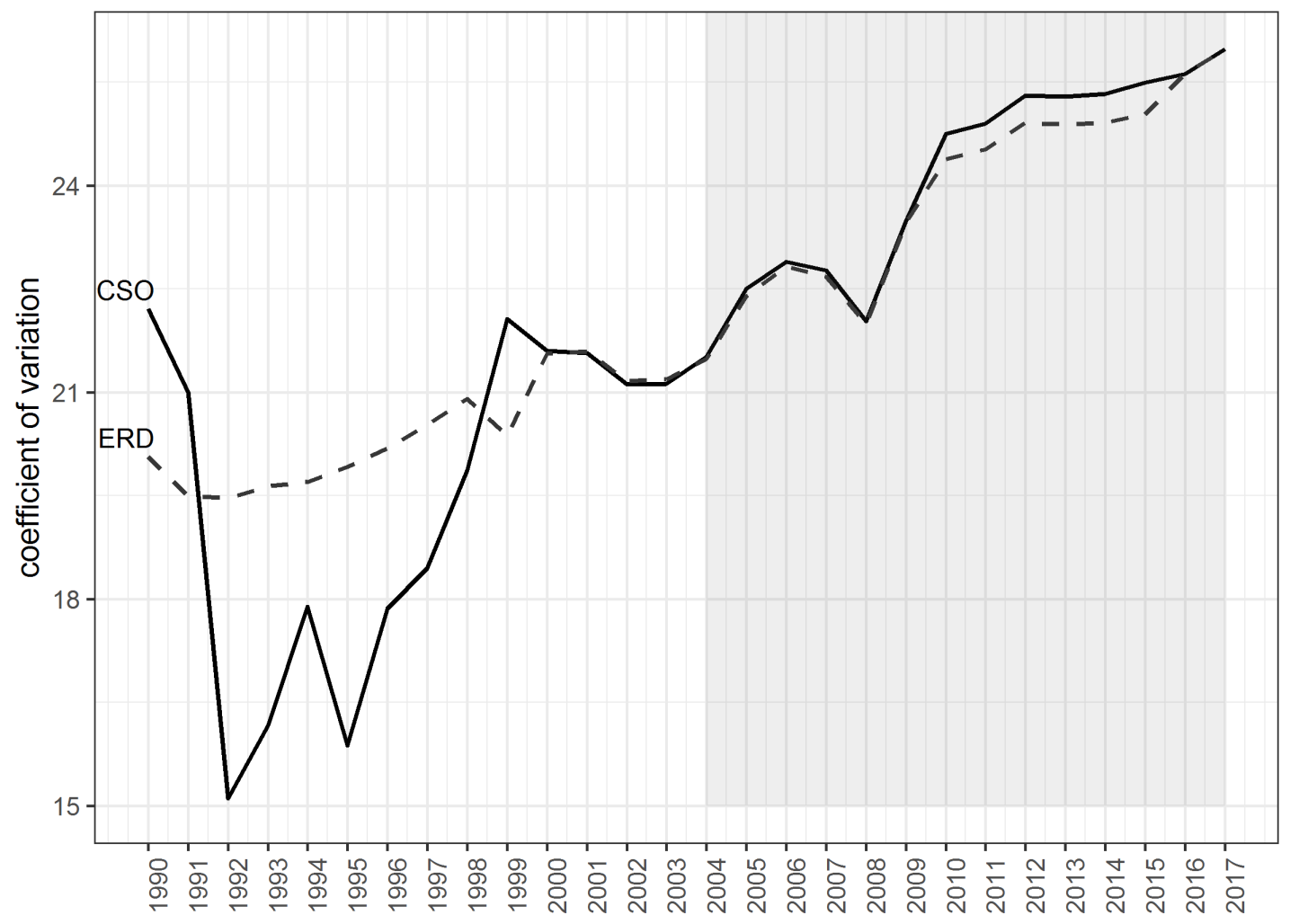

Figure 4. Coefficient of variation of relative GDP per capita in Polish regions in 1990-2017 Source: own calculation based on data from CSO and ERD

Table 4. Results (p-value) of the test of the equality of slopes of the trends of regional inequality measure before and after Poland's EU accession

\begin{tabular}{|c|c|c|c|c|c|c|c|c|c|}
\hline \multirow{2}{*}{ test and data } & \multicolumn{9}{|c|}{ number of years before and after $\mathbf{2 0 0 4}$} \\
\cline { 2 - 12 } & $\mathbf{5}$ & $\mathbf{6}$ & $\mathbf{7}$ & $\mathbf{8}$ & $\mathbf{9}$ & $\mathbf{1 0}$ & $\mathbf{1 1}$ & $\mathbf{1 2}$ & $\mathbf{1 3}$ \\
\hline t-test, CSO & 0,77 & 0,87 & 0,98 & 0,75 & 0,91 & 0,78 & 0,66 & 0,63 & 0,53 \\
\hline t-test, ESD & 0,50 & 0,48 & 0,51 & 0,14 & 0,49 & 0,50 & 0,42 & 0,36 & 0,24 \\
\hline Wilcoxon test, CSO & 1,00 & 1,00 & 0,94 & 0,95 & 1,00 & 0,85 & 0,90 & 1,00 & 1,00 \\
\hline Wilcoxon test, ERD & 0,81 & 0,56 & 0,30 & 0,15 & 0,65 & 0,49 & 0,46 & 0,30 & 0,22 \\
\hline
\end{tabular}

Source: own calculations based on CSO and ERD

average slopes of lines (t-test) are equal, or that the distributions of slope lines are equal (Wilcoxon) - cannot be rejected. As a further sensitivity analysis we employed both tests for different cut-off years - not only 2004, but also 2000, 2002, 2006 and 2008 (not presented here but available upon request). The hypothesis that the pattern of sigma convergence was the same for the two periods was never rejected. One can therefore conclude that EU accession did not have a significant impact on the pattern of internal sigma convergence in Poland: disparities between regions increased at the same pace before and after 2004.

Next, we tested a more restrictive variant of parallel sigma convergence - the assumption that the changes of inequality measures year by year were exactly equal in both periods (i.e. parallel black lines from Figure 5 and MADiS $=0$ ) or that at least inequalities changed in the same direction year by year in both periods (MADiSS $=0$ ). Again we applied tests for 5-, 6-, .., 13year periods before and after EU accession. Results of all tests are presented in Table 5.

The restrictive hypothesis that MADiS $=0$ is rejected in every case, as expected. However, for a comparison of 8-13year periods it takes relatively low values $(0.5-0.7)$. This means that although the dynamics of sigma convergence before and after EU accession was not identical year by year, it was quite similar. That is why the hypothesis of MADiSS $=0$ cannot be rejected in many cases (in case of ERD for $k=5,7,8,10$; in the case of CSO for $k=5,6,7,11)$. This at least partly confirms that 


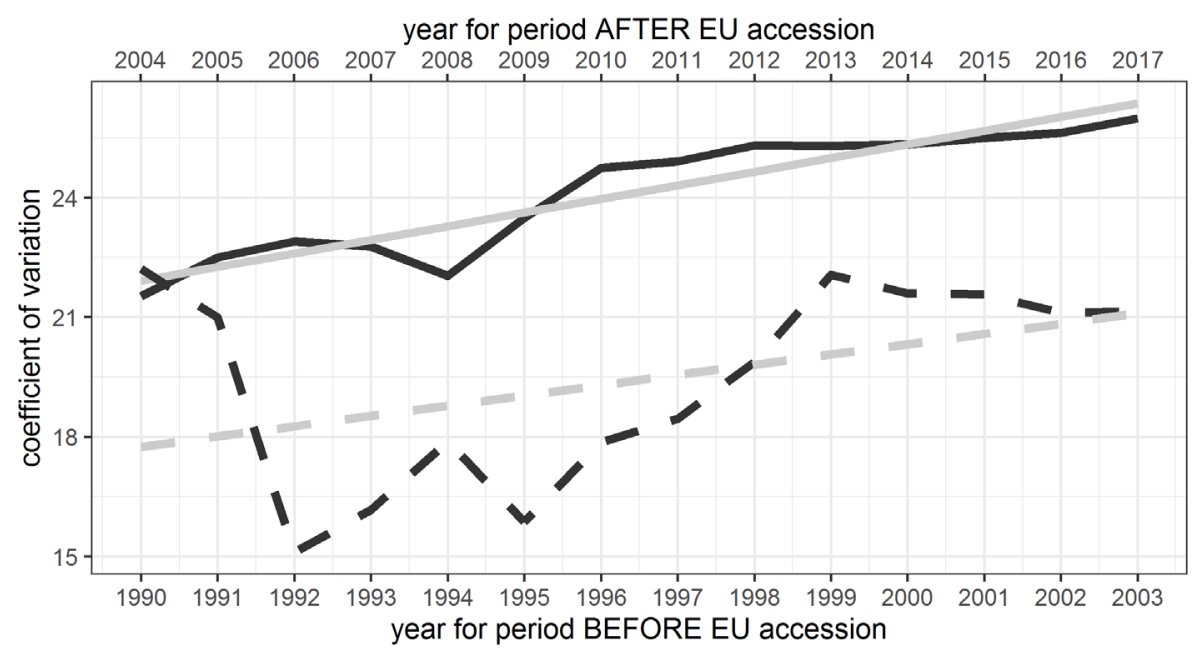

period

data

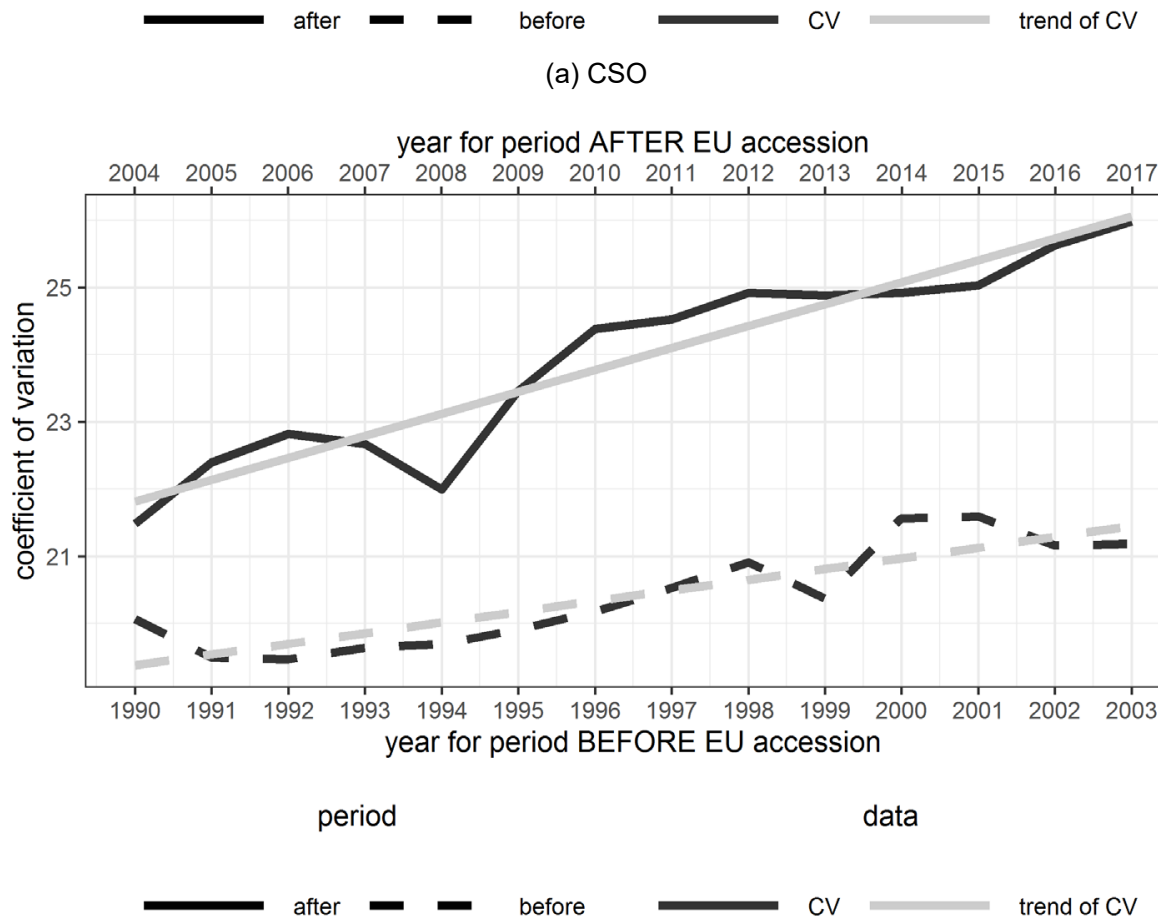

(b) ERD

Figure 5. Coefficient of variation of relative GDP per capita in Polish regions - direct comparison of 14-year, pre- and post-accession periods

regional inequalities in Poland before and after 2004 changed in the same direction year by year. In both subperiods inequalities were gradually increasing, which can be seen especially in the ERD data (compare black lines on Figure $5 b$ ).

\section{Summary and conclusions}

Real economic convergence is a long-term phenomenon, but, for Poland, research at a regional level usually covers short periods. Evaluation of Cohesion Policy in Poland shows that all regions are catching up with the EU28 average (external convergence). The closing of the gap by eastern regions is to a large extent a result of EU funds. However, disparities between regions are still increasing. In this study we analyzed the dynamics of regional disparities in Poland for the longest period ever analyzed (1990-2017). We focused on the comparison of patterns of regional convergence before and after EU accession with the methodology of parallel sigma convergence. The picture does not seem to differ much for the two subperiods - regional sigma divergence is observed in both of them. Mazowieckie grew much faster than the average, while eastern regions lagged behind. Regional inequalities increased in the same way before and after 2004. The hypothesis that the dynamics (slope) of income inequalities were identical before and after EU accession cannot be rejected. In several cases even the 
MISCELLANEA GEOGRAPHICA - REGIONAL STUDIES ON DEVELOPMENT

Vol. 25 • No. 2 - 2021 • pp. 83-92 • ISSN: 2084-6118 • DOI: 10.2478/mgrsd-2020-0050

Table 5. Results of the tests for MADiS and MADiSS

\begin{tabular}{|c|c|c|c|c|c|c|c|c|c|}
\hline \multirow{2}{*}{ test and data } & \multicolumn{9}{|c|}{ number of years before and after 2004} \\
\cline { 2 - 11 } & $\mathbf{5}$ & $\mathbf{6}$ & $\mathbf{7}$ & $\mathbf{8}$ & $\mathbf{9}$ & $\mathbf{1 0}$ & $\mathbf{1 1}$ & $\mathbf{1 2}$ & $\mathbf{1 3}$ \\
\hline MADiS, CSO & $0.78^{*}$ & $1.07^{*}$ & $1.05^{*}$ & $1.24^{*}$ & $1.22^{*}$ & $0.91^{*}$ & $0.96^{*}$ & $1.35^{\star}$ & $1.66^{\star}$ \\
\hline MADiS, ESD & $0.81^{*}$ & $1.06^{*}$ & $0.82^{*}$ & $0.44^{*}$ & $0.63^{*}$ & $0.69^{*}$ & $0.56^{*}$ & $0.63^{*}$ & $0.63^{*}$ \\
\hline MADiSS, CSO & 0,4 & 0,33 & 0,86 & $1.25^{*}$ & $1.56^{*}$ & $1.00^{*}$ & 0,55 & $0.67^{*}$ & $1.38^{*}$ \\
\hline MADiSS, ERD & 0,8 & $1.33^{*}$ & 0,57 & 0,5 & $1.11^{*}$ & 0,6 & $0.91^{*}$ & $1.00^{*}$ & $0.77^{*}$ \\
\hline
\end{tabular}

Source: own calculation based on CSO and ERD

Note: * means rejection of the null hypothesis that MADiS $=0$ or MADiSS $=0$ with $95 \%$ confidence.

more restrictive assumption that the direction of year-by-year changes of inequalities in two compared periods was the same is confirmed. Therefore, Poland's accession to the European Union did not have a significant impact on the dynamics of regional convergence processes. Despite significant resources aimed at cohesion having been allocated after EU accession, especially in lagging eastern regions, the patterns of internal convergence did not change after 2004 and development gaps continued to grow. Previous research has indicated that all regions would have grown at a slower pace without EU membership and that the poorest Polish regions gained most from the accession. However, after 2004 the initially richest regions developed even faster than before, which has accelerated divergence processes in Poland. The impact of the Cohesion Policy was not strong enough to fully offset these tendencies, but slowed the process of divergence.

\section{Acknowledgements}

This work was supported by the National Science Center in Poland under Grant number 2016/21/B/HS4/00670.

ORCID

Piotr Wójcik (1D) https://orcid.org/0000-0003-1853-8784

\section{References}

Barro, R \& Sala-i-Martin, X 1992, 'Convergence', Journal of Political Economy, vol. 100, pp. 223-251.

Barro, R \& Sala-i-Martin, X 2004, Economic growth, The MIT Press, 2nd edition, Cambridge..

Churski, P \& Perdał, R 2016, 'Where do Cohesion Policy funds flow and do they have any impact? The Polish lesson', Barometr Regionalny, vol. 14, no. 3, pp. 7-24.

Czudec, A \& Kata, R 2016, 'Processes of regional convergence in Poland in the context of the use of European Union Funds', Lex Localis - Journal of local self-government, vol. 14, no. 4, pp. 715-737.

Czyżewski, AB 1998, Regional Development of Poland 19861996. Measurement and Analysis, World Bank Report, Warsaw.

Efron, B 1987, 'Better bootstrap confidence intervals', Journal of the American Statistical Association, vol. 82, no. 397, pp. 171-185.

ERD 2017, European Regional Database manual, last revised on 25.05.2017. Available from: <http://www.camecon.com/wpcontent/uploads/2019/01/ERD-manual.pdf>. [10 December 2019].

Herz, B \& Vogel, L 2013, 'Regional convergence in Central and Eastern Europe: Evidence from a decade of transition'. Available from: <https://ssrn.com/abstract=988275>. [10 December 2019].

Horridge, M \& Rokicki, B 2018, 'The impact of European Union accession on regional income convergence within the Visegrad countries', Regional Studies, vol. 52, no. 4, pp. 503515.

Kusideł, E 2013, Konwergencja gospodarcza w Polsce $i$ jej znaczenie w osiąganiu celów polityki spójności [Economic convergence in Poland and its importance in achieving the goals of the cohesion policy], Wydawnictwo Uniwersytetu Łódzkiego, Łódź.

Piętak, Ł 2015, 'Convergence across Polish regions 2005-2011', Comparative Economic Research, vol. 18, no. 2, pp. 99-118.
Próchniak, M 2004, 'Analiza zbieżności wzrostu gospodarczego województw w latach 1995-2000' ['Analysis of convergence of economic growth in voivodships in 1995-2000'], Gospodarka Narodowa, no. 3, pp. 27-44.

Wałęga, A 2014, 'Spójność ekonomiczna regionów Polski przed i po przystąpieniu do Unii Europejskiej' ['Economic cohesion of Polish regions before and after joining the European Union'], Studia Ekonomiczne, no. 203, pp. 172-180.

Wędrowska, E \& Wojciechowska, K 2015, 'Konwergencja gospodarcza w województwach Polski w latach 2000-2012' ['Economic convergence in Polish voivodships in 20002012'] Roczniki Kolegium Analiz Ekonomicznych SGH, no. 36, pp. 403-412.

Wojtowicz, D 2020, Pomoc rozwojowa sukces czy porażka. Krytyczna analiza wpływu polityki spójności UE na rozwój regionalny $i$ lokalny w Polsce [Development aid, success or failure. Critical analysis of the impact of the EU cohesion policy on regional and local development in Poland], Poltext, Warszawa

Wójcik, P 2017, 'Was Poland the next Spain? Parallel analysis of regional convergence patterns after accession to the European Union', Equilibrium. Quarterly Journal of Economics and Economic Policy, vol. 2 no. 4, pp. 593-611.

Wójcik, P 2018, Metody pomiaru realnej konwergencji gospodarczej w ujęciu regionalnym i lokalnym. Konwergencja równoległa [Methods for measuring real economic convergence in regional and local level. Parallel convergence], Wydawnictwa Uniwersytetu Warszawskiego, Warszawa.

Zienkowski, L 2000, 'Regional pattern of economic growth in Poland, 1995-1998', Główny Urząd Statystyczny. Research Bulletin, vol. 9, no. 3-4. 